(1)

\title{
Estetrol is a weak estrogen antagonizing estradiol-dependent mammary gland proliferation
}

C Gérard, S Blacher, L Communal', A Courtin', E Tskitishvili, M Mestdagt, C Munaut, A Noel, A Gompel ${ }^{1,2}$, C Péqueux ${ }^{*}$ and J M Foidart ${ }^{*}$

Laboratory of Tumor and Development Biology, GIGA-Cancer, Institute of Pathology, University of Liège, CHU-B23, B-4000 Liège, Belgium

${ }^{1}$ INSERM-UMRS 938, Université Pierre et Marie Curie (UPMC), F-75005 Paris, France

${ }^{2}$ Gynaecological Endocrinology Unit, Paris Descartes University, Hôpitaux Universitaires, F-75006 Paris, France

*(C Péqueux and J M Foidart contributed equally to this work)

Correspondence

should be addressed

to $C$ Péqueux

Email

C.Pequeux@ulg.ac.be

\begin{abstract}
Estetrol $\left(E_{4}\right)$ is a natural estrogen produced exclusively by the human fetal liver during pregnancy. Its physiological activity remains unknown. In contrast to ethinyl estradiol and estradiol $\left(E_{2}\right), E_{4}$ has a minimal impact on liver cell activity and could provide a better safety profile in contraception or hormone therapy. The aim of this study was to delineate if $E_{4}$ exhibits an activity profile distinct from that of $E_{2}$ on mammary gland. Compared with $E_{2}, E_{4}$ acted as a low-affinity estrogen in both human in vitro and murine in vivo models. $\mathrm{E}_{4}$ was 100 times less potent than $E_{2}$ to stimulate the proliferation of human breast epithelial (HBE) cells and murine mammary gland in vitro and in vivo respectively. This effect was prevented by fulvestrant and tamoxifen, supporting the notion that ER $\alpha$ (ESR1) is the main mediator of the estrogenic effect of $E_{4}$ on the breast. Interestingly, when $E_{4}$ was administered along with $E_{2}$, it significantly antagonized the strong stimulatory effect of $E_{2}$ on HBE cell proliferation and on the growth of mammary ducts. This study characterizes for the first time the impact of $E_{4}$ on mammary gland. Our results highlight that $E_{4}$ is less potent than $E_{2}$ and exhibits antagonistic properties toward the proliferative effect of $E_{2}$ on breast epithelial cells. These data support $E_{4}$ as a potential new estrogen for clinical use with a reduced impact on breast proliferation.
\end{abstract}

Key Words

$\begin{aligned} & \text { Key Words } \\ & \text { - estetrol } \\ & \text { - mammary gland } \\ & \text { - proliferation } \\ & \text { - estrogen receptor alpha } \\ & \text { - agonist/antagonist } \\ & \text { - menopause } \\ & \text { - contraception }\end{aligned}$

\section{Introduction}

$17 \beta$-estradiol $\left(\mathrm{E}_{2}\right)$ stimulates postnatal mammary gland development by driving and coordinating proliferation and differentiation through paracrine interactions (Anderson et al. 1998, Russo \& Russo 1998, Brisken \& O'Malley 2010). Prolonged exposure to endogenous estrogens in case of early age at menarche or late menopause increases the risk of breast cancer development, while an early menopause has a protective effect
(Fenton 2006, Rudel et al. 2011). Interestingly, early pregnancy, which is associated with extremely high levels of estrogen exposure to women, exhibits a dual effect on the risk of the breast cancer development (Lambe et al. 1994).

A major harmful effect of oral estrogen for menopausal hormone therapy (MHT) or combined oral contraceptive (COC) users is an imbalance in hemostasis leading 
to a global enhancement of thrombin generation that increases the risk of venous thromboembolism (Canonico 2014, O'Brien 2014, Scarabin 2014). In addition, several studies have linked the use of exogenous estrogen preparations to the risk of initiating breast cancer (Stahlberg et al. 2004, Lai et al. 2011, Turkoz et al. 2013). The combined administration of equine estrogen plus progestin, and, to a lesser extent, estrogen alone to postmenopausal women increases the risk of breast cancer (Rossouw et al. 2002, Anderson et al. 2006, Foidart et al. 2007, Sturdee et al. 2011). A new estrogen with a safer profile is therefore required to improve women's health during and after their fertile lifetime.

Estetrol $\left(\mathrm{E}_{4}\right)$ is a human-specific natural estrogen produced only during pregnancy by the fetal liver (Coelingh Bennink et al. 2008a, Holinka et al. 2008a). It was initially identified by Hagen et al. (1965), but its physiological role during pregnancy remains to be defined. $\mathrm{E}_{4}$ maternal plasma levels reach $1 \mathrm{ng} / \mathrm{ml}(3 \mathrm{nM})$, and $0.5-3.8 \mathrm{mg} /$ day of $\mathrm{E}_{4}$ have been measured in urine at the end of pregnancy, suggesting that exposure to a high level of $\mathrm{E}_{4}$ is not toxic. $\mathrm{E}_{4}$ binds to both estrogen receptors, with a higher affinity for estrogen receptor alpha (ER $\alpha-$ ESR1) (Visser et al. 2008). In experimental animal models and in clinical studies in women, $\mathrm{E}_{4}$ acts as an estrogen to prevent vaginal dryness, osteoporosis, and hot flushes (Coelingh Bennink et al. 2008b, Holinka et al. 2008b, Visser et al. 2008). In contrast to $\mathrm{E}_{2}$, it exhibits a high oral bioavailability with an elimination half-life of $28 \mathrm{~h}$ in humans. It does not stimulate the production of nor bind to the sex hormone-binding globulin (Hammond et al. 2008) and it has no or only a minimal impact on liver function. When used at $5-20 \mathrm{mg}$ in a phase 2 clinical trial (Foidart, JM. Congress of Eur. Soc. Gynecol. 2013, personal communication), $\mathrm{E}_{4}$ induces minimal changes compared with ethinyl estradiol (EE) in binding cortisol globulin, angiotensinogen, triglycerides, or estrogensensitive coagulation proteins. Due to these unique pharmacological properties, $\mathrm{E}_{4}$ appears to be suitable as a potential drug for contraception or MHT. However, nothing is known about the potential impact of $\mathrm{E}_{4}$ on the normal breast.

The aim of this work was to investigate the proliferative activity of $\mathrm{E}_{4}$ on the mammary cells in an in vitro model of isolated human breast epithelial (HBE) cells and an in vivo model of mouse mammary gland growth, coupled with a robust quantification performed by computer-assisted image analysis. To our knowledge, our study is the first one to describe the impact of $\mathrm{E}_{4}$ on normal breast.

\section{Materials and methods}

\section{Chemicals, reagents, and steroids}

HAM's F10 medium, FCS, $\mathrm{NaHCO}_{3}$ solution, Hank's balanced salt solution, and sterile trypsin solution were obtained from Life Technologies. EDTA, penicillinstreptomycin, cholera toxin, transferrin, insulin, triiodothyronine, cortisol, estradiol, tamoxifen, ICI 182780 (fulvestrant), hyaluronidase, and carmin were obtained from Sigma-Aldrich. Epidermal growth factor and collagenase were obtained from Boehringer Mannheim Chemical Corp. Human serum was obtained from the 'Etablissement Français du Sang' of the Saint Antoine Hospital (Paris, France). [Methyl- ${ }^{3} \mathrm{H}$ ] thymidine was obtained from GE Healthcare (Buckinghamshire, UK). $\mathrm{E}_{4}$ was supplied by Uteron Pharma (Liège, Belgium).

\section{Ethical approval}

Human mammary epithelial cells were obtained from women undergoing reduction mammoplasty for aesthetic purposes. All patients gave their informed consent for the studies according to the French law on clinical experimentation ('Comité de protection des Personnes', biomedical project 11826). All of the animal procedures of this study were approved by the animal ethical committee of University of Liège (Belgium).

\section{Human mammary epithelial cell culture}

Specimens of normal breast epithelial cells were obtained from women (aged 15-42 years). The patients had no history of breast disease and pathological examination of the tissue showed only normal breast tissue. Briefly, the tissue was digested with collagenase $(0.15 \%)$ and hyaluronidase (0.05\%) in HAM's F10 medium, and then filtered consecutively through 300 and $150 \mu \mathrm{m}$ sieves to retain undigested tissue. The cells were pelleted, distributed into T25 plastic flasks, and maintained at $37^{\circ} \mathrm{C}$ in a humidified atmosphere with $5 \% \mathrm{CO}_{2}$. The HBE cells were maintained in HAM's medium containing $\mathrm{NaHCO}_{3}(0.24 \%)$, penicillin-streptomycin (1\%), cortisol $(5 \mathrm{ng} / \mathrm{ml})$, T3 $(6.5 \mathrm{ng} / \mathrm{ml})$, choleratoxin $(10 \mathrm{ng} / \mathrm{ml})$, transferrin $(5 \mathrm{mg} / \mathrm{ml})$, insulin $(0.016 \mathrm{U} / \mathrm{ml})$, EGF $(10 \mathrm{ng} / \mathrm{ml})$ and $5 \%$ human serum. Proliferation tests were assessed with these fresh cells.

\section{Proliferation assay}

Forty-eight hours after exposure to hormones, cells were incubated with $2 \mu \mathrm{Ci}$ of [methyl- ${ }^{3} \mathrm{H}$ ] thymidine for $48 \mathrm{~h}$

Published by Bioscientifica Ltd. 
at $37^{\circ} \mathrm{C}$. After incubation, the cells were washed twice with PBS and twice with 5\% trichloroacetic acid. The cells were incubated in $5 \%$ TCA for $15 \mathrm{~min}$ at $4{ }^{\circ} \mathrm{C}$ and lysed in $\mathrm{NaOH} 0.1 \mathrm{M}$ for $15 \mathrm{~min}$ at $37^{\circ} \mathrm{C}$. The total cell lysate was added to $25 \mu \mathrm{l}$ of scintillation liquid and radioactivity was counted with a Beckman (Fullerton, CA, USA) LS-500-CE $\beta$ counter.

\section{Prepubertal mouse study experimental design}

C57BL/6 female prepubertal mice were purchased from Janvier Laboratory (Saint-Berthevin, France). Five mice per cage were housed under a standard 12-h photoperiod. Food and water were provided ad libitum. Mice were ovariectomized (OVX) at 28 days of age under isoflurane anesthesia to remove endogenous hormone production. Oral treatment was initiated at 35 days of age for a period of 6 or 14 days. Mice were fed by gavage with peanut oil containing $5 \%$ ethanol (vehicle, negative control) or $\mathrm{E}_{4}$ $(0.3,1,3$, or $10 \mathrm{mg} / \mathrm{kg}$ per day) alone or in combination with $\mathrm{E}_{2}\left(1 \mathrm{mg} / \mathrm{kg}\right.$ per day). $\mathrm{E}_{2}$ and $\mathrm{E}_{4}$ were dissolved in absolute ethanol and brought to the final concentration with peanut oil (5\% EtOH in peanut oil). At the end of treatment, mice were killed; mammary tissues were dissected for wholemount preparation and epithelial RNA isolation or paraffinembedded for histological analyses. Plasma was isolated from blood (cardiac puncture) and circulating hormone concentration was determined by mass spectrometry (ATC Pharma, Liège, Belgium). The animals were weighed before and after treatment. The experimentation was performed with five animals in each group.

\section{Mammary gland whole mount}

Murine mammary gland growth is a particularly sensitive method largely used to study the impact of various compounds directly on the mammary epithelium (Ayyanan et al. 2011) and to define the molecular mechanisms driving mammary gland development (Mallepell et al. 2006, Beleut et al. 2010). One of the fourth inguinal mammary glands was removed in one piece and spread onto a glass slide. The removed gland was subjected to whole-mount fixation, defatting, and staining. The mammary glands were fixed in Carnoy's fixative (ethanol, chloroform, glacial acetic acid; 6:3:1) for at least $4 \mathrm{~h}$ and defatted in acetone overnight. They were then rehydrated through a series of graded alcohols and stained with carmine overnight. The whole-mount glands were then dehydrated sequentially through 70,90 , and $100 \%$ ethanol for $20 \mathrm{~min}$ each and cleared in xylene for at least $2 \mathrm{~h}$. Digital pictures of mammary glands immersed in xylene were taken using a Leica M80 microscope with a Leica IC80 HD digital camera attached.

\section{Image processing and morphological measurements}

To quantify the morphological changes occurring under the various treatments in mouse mammary gland, we developed an original computer-assisted method of quantification. Digital pictures of mammary gland whole mounts allowed an assessment of morphological features by image analysis. Image processing and measurements were implemented with the image analysis toolbox of Matlab7.9, Mathworks (Natick, MA, USA). Mammary gland structure was extracted using the Frangi multiscale filter (Frangi et al. 1998) that allows the identification of elongated objects having a characteristic thickness, in images presenting nonhomogeneous intensities. The resulting images were then binarized, i.e., pixel values belonging to mammalian glands take the value equal to 1 and 0 background pixels. Finally, morphological filters (Soille 1999) were used to eliminate noise remaining in the images. The resulting binary images were then systematically compared with the original ones and corrected manually if required. Total area of the epithelial network, also named ductal tree $\left(\mathrm{mm}^{2}\right)$, was calculated from binary images that were further skeletonized (Soille 1999) in order to measure the total length $(\mathrm{mm})$. Total area and total length of the ductal tree are two parameters reflecting the growth rate of the mammary gland. Furthermore, to evaluate gland differentiation, proliferating units of the mammary gland named terminal end buds (TEBs) were automatically detected on mammary glands collected after 6 and 14 days. As they appear as the darkest features located at the periphery of the mammary gland, binary images of TEBs were obtained using an appropriate threshold and a size filter. Only buds with diameter $>100 \mu \mathrm{m}$ were considered as TEB (LaRocca et al. 2011). From those images, the total number of TEBs were measured.

\section{$\mathrm{Ki67}, \mathrm{ER} \alpha$, and progesterone receptor immunohistochemistry}

To carry out histological analysis, samples were fixed in $4 \%$ formalin for $2 \mathrm{~h}$ and stored in $70 \%$ ethanol before paraffin embedding. The sections were cut at $6 \mu \mathrm{m}$. For detection of Ki67, ER $\alpha$, and progesterone receptor (PGR) in the mammary gland, the slides were deparaffinized in xylene and rehydrated through graded alcohols. For antigen retrieval, sections were heated at $126^{\circ} \mathrm{C}$ under

Published by Bioscientifica Ltd. 
1.4 Bar in $10 \mathrm{mM}$ citrate buffer for $10 \mathrm{~min}$. The sections were then treated with $3 \% \mathrm{H}_{2} \mathrm{O}_{2}$ for 20 min to block endogenous peroxidase activity, washed with PBS, and incubated with $10 \%$ BSA for $1 \mathrm{~h}$. After blocking, the sections were incubated with the Ki67 antibody (TEC-3 rat monoclonal IgG) from Dako (Glostrup, Denmark), the ER $\alpha$ antibody (MC-20 rabbit polyclonal IgG) from Santa Cruz Biotechnology, or the PGR antibody (SP2 rabbit monoclonal IgG) from Thermo Scientific (Waltham, MA, USA) at 1:50, 1:25, and 1:400 dilutions respectively. The slides were then incubated with biotinylated secondary antibodies for $30-\mathrm{min}$, followed by $30 \mathrm{~min}$ incubation with streptavidin-peroxidase conjugate. Antigenantibody complex was visualized by incubation with 3,3'-diaminobenzidine 5 . The slides were counterstained with hematoxylin, dehydrated, and mounted using a mounting medium from Labonord (Templemars, France). Positively stained cells appeared brown while negative cells were blue.

\section{Epithelial cell isolation from mouse mammary gland}

Mice were killed by cervical dislocation and both fourth mammary glands were dissected. The proximal and distal parts of the mammary glands were collected in DMEM/F12 supplemented with collagenase $(0.10 \%)$ and hyaluronidase $(0.05 \%)$, but the central part containing the lymph node was discarded. Tissue was minced and incubated under constant agitation for $1 \mathrm{~h}$ at $37^{\circ} \mathrm{C}$. After centrifugation at $450 \boldsymbol{g}$ for $5 \mathrm{~min}$, organoids were suspended in cold HBSS, and then five pulse centrifugations reaching $450 \mathrm{~g}$ were performed. The final pellet should contain mainly epithelial structures. Single cells, fibroblasts, and blood cells were discarded with the supernatant.

\section{Quantitative RT-PCR}

RNA was extracted using TRIzol reagent (Invitrogen) from the epithelial cells isolated from mouse mammary gland, following the manufacturer's protocol. RT and real-time quantitative PCR were performed using specific primers and Brilliant SYBR GREEN QPCR master mix on a Roche apparatus. Sequence primers for target genes were $\left(5^{\prime}\right.$ to $3^{\prime}$ ): glyceraldehyde-3-phosphate dehydrogenase (Gapdh) forward GTTCACCCACTAATAGGG and reverse GGATTCTGACTTAGAGGCGTT; $P g r$ forward GCCCACAGTATGGCTTTGATTCCT and reverse GCAACACCGTCAAGGGTTCTCATA; Mki67 (Ki67) forward GATAGCTTCTGTGCTGACCCTGAT and reverse CCCTGATGAGTCTTGGCTAACACT; Cond1 (cyclin D1) forward
GAGCTGCTGCAAATGGAACTGCTT and reverse GTTCTCATCCGCCTCTGGCATTTT. Gene expression values were normalized to housekeeping gene Gapdh.

\section{Statistical analyses}

All quantitative experimental data are expressed as mean \pm s.D. or mean \pm s.E.M. Statistical analyses were conducted with GraphPad Prism Software (La Jolla, CA, USA) using one-way ANOVA followed by Student-NewmanKeuls's test or using Kruskal-Wallis followed by Dunn's test, with regard to heteroscedasticity. A $P$ value of $\leq 0.05$ was considered as statistically significant.

\section{Results}

$E_{4}$ is an estrogen with low affinity, which stimulates HBE cell proliferation at high doses

Exposure of $\mathrm{HBE}$ cells for $96 \mathrm{~h}$ to $10 \mathrm{nM} \mathrm{E} \mathrm{E}_{2}$ elicited a maximal cell proliferation increase by $60 \%$ (Fig. 1A). A tenfold higher $E_{2}$ concentration failed to further stimulate proliferation. $10 \mathrm{nM} \mathrm{E}_{4}$ did not increase $\mathrm{HBE}$ cell proliferation (Fig. 1B). A 100-fold higher concentration was necessary to stimulate the proliferation rate to the same extent, indicating that $\mathrm{E}_{4}$ is a low affinity estrogen in HBE cells.

\section{$E_{4}$ promotes mammary gland growth and proliferation in OVX mice}

The in vivo impact of a daily oral treatment with $\mathrm{E}_{4}$ was analyzed on mammary gland of OVX mice after 6 or 14 days and quantified using an original computer-assisted
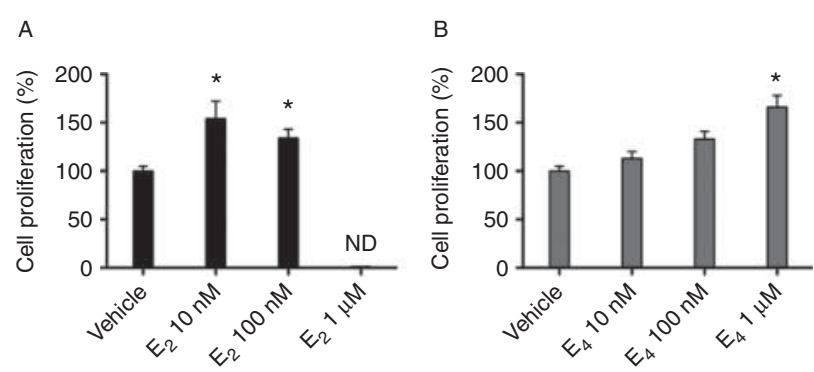

Figure 1

Effect of $E_{4}$ and $E_{2}$ on HBE cell proliferation. Histograms of HBE cell proliferation determined by $\left[{ }^{3} \mathrm{H}\right]$ thymidine incorporation after $96 \mathrm{~h}$ of treatment. (A) Treatment with $E_{2}$ (10 and $\left.100 \mathrm{nM}\right)$. (B) Treatment with $\mathrm{E}_{4}$ $(10 \mathrm{nM}, 100 \mathrm{nM}$, and $1 \mu \mathrm{M})$. Data are expressed as \% of control normalized at $100 \%$, mean \pm s.E.M., $n=3$. ${ }^{*} P<0.05$ vs vehicle. HBE, human breast epithelial, ND, not determined.

Published by Bioscientifica Ltd 
A

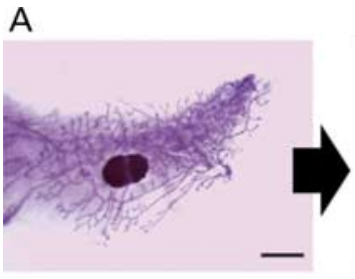

c

$\mathrm{E}$
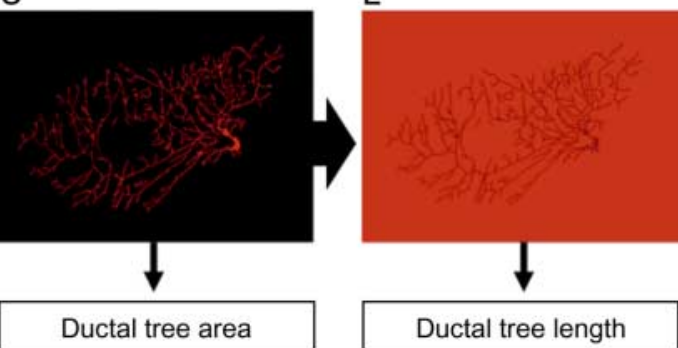

Ductal tree area

Ductal tree length

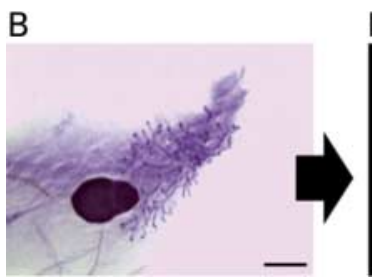

D

\section{Figure 2}

Computer-assisted method of mammary gland quantification. Morphological parameters of the mammary glands were quantified with a computer-assisted method. Whole-mount mammary glands after 14 days (A) and 6 days (B) of estrogenic treatment. (C) Binary image of the matched whole-mount mammary gland used to measure the total area occupied by

image analysis method (Fig. 2). $\mathrm{E}_{4}$ (3 mg/kg per day) induced the growth of the prepubertal epithelial ducts and the appearance of TEBs (Fig. 3A). The mammary gland growth rate was quantified by measuring the total length the ductal tree. (D) Binary image where green dots indicate detected TEBs that were counted. (E) Skeletonized binary image used to measure ductal tree length. Scale bars $=2 \mathrm{~mm}$. TEB, terminal end bud. A full colour version of this figure is available via http://dx.doi.org/10.1530/JOE-14-0549.

and total area of the epithelial ductal tree (Fig. 3B and C). After 6 days of treatment, the average total length and area of the epithelial network were increased by 2.18- and 2.13-fold in $\mathrm{E}_{4}$-treated mice respectively. TEBs were
A

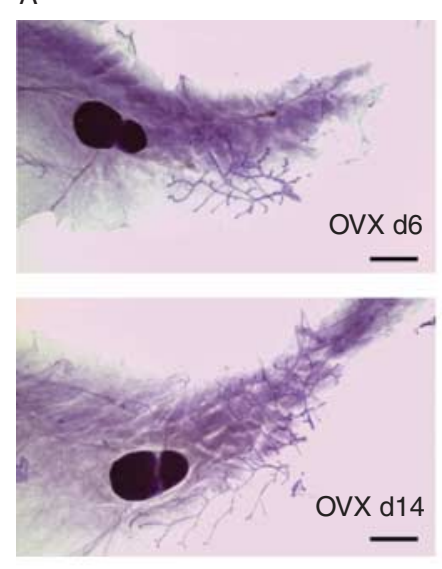

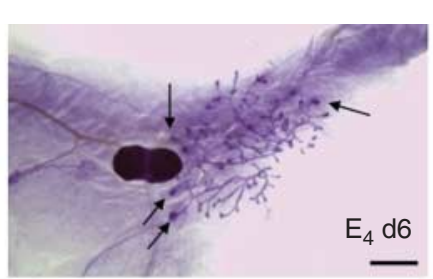

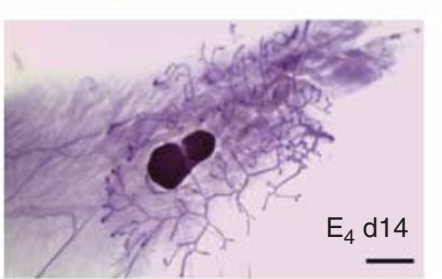

B

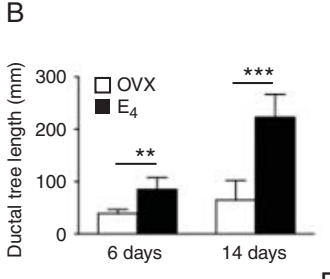

D

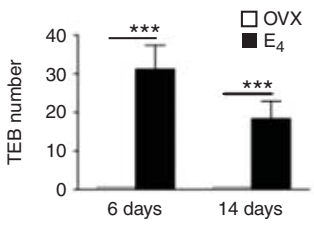

C

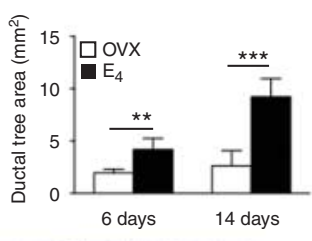

E

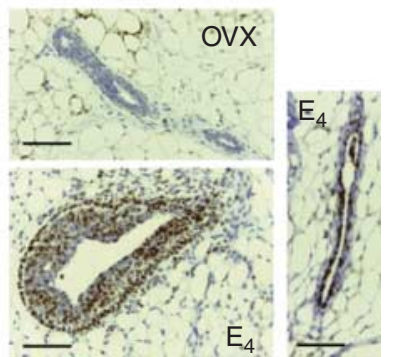

\section{Figure 3}

Effect of $E_{4}$ on mouse mammary gland growth and proliferation. (A) Whole-mount mammary gland from ovariectomized mice orally treated with vehicle $(\mathrm{OVX})$ or from ovariectomized mice orally treated with $\mathrm{E}_{4}$ at $3 \mathrm{mg} / \mathrm{kg}$ per day $\left(E_{4}\right)$ for a period of $6(\mathrm{~d} 6)$ or 14 (d14) days. TEBs are pointed by arrows. Scale bars $=2 \mathrm{~mm}$. (B, C, and D) Computer-assisted quantification of the morphological parameters of whole-mount mammary glands from ovariectomized mice orally treated with vehicle (OVX) or from ovariectomized mice orally treated with $\mathrm{E}_{4} 3 \mathrm{mg} / \mathrm{kg}$ per day $\left(\mathrm{E}_{4}\right)$ for a period of 6 (d6) or 14 (d14) days. Mammary gland morphology was assessed with three parameters: total length (B) and area (C) of the ductal tree, and number of TEBs (D). Note the total lack of TEBs in control groups (OVX). Data are presented as mean \pm S.E.M., $n=5$. ${ }^{*} * P<0.01, * * * P<0.001$ vs OVX. (E) Histological sections of mammary gland, stained with an anti-Ki67 antibody, from OVX or $\mathrm{E}_{4}$ ( $3 \mathrm{mg} / \mathrm{kg}$ per day)-treated mice after 6 days. Lower left panel, TEB section; right panel, epithelial duct section. Scale bars $=100 \mu \mathrm{m}$. TEB, terminal end bud. A full colour version of this figure is available via http://dx.doi.org/10.1530/JOE-14-0549. http://joe.endocrinology-journals.org DOI: 10.1530/JOE-14-0549
() 2015 Society for Endocrinology Printed in Great Britain 
A
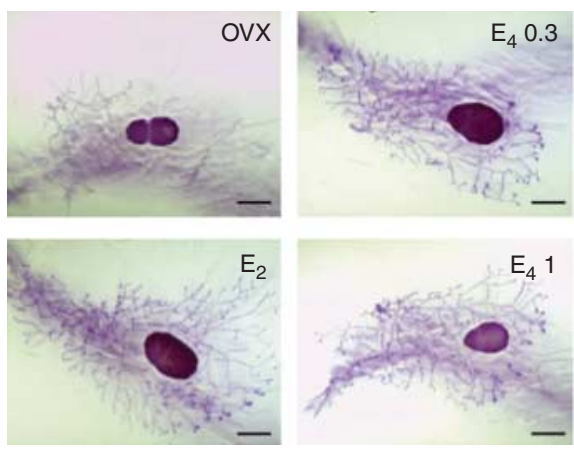

$E_{2}$

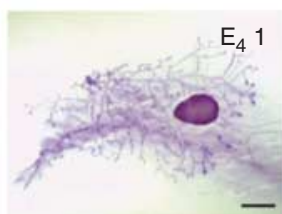

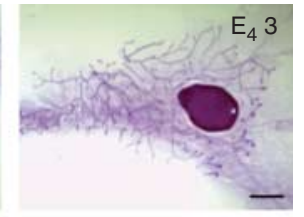

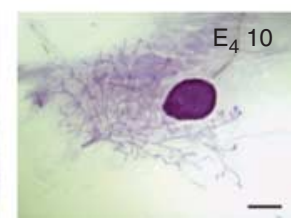

B
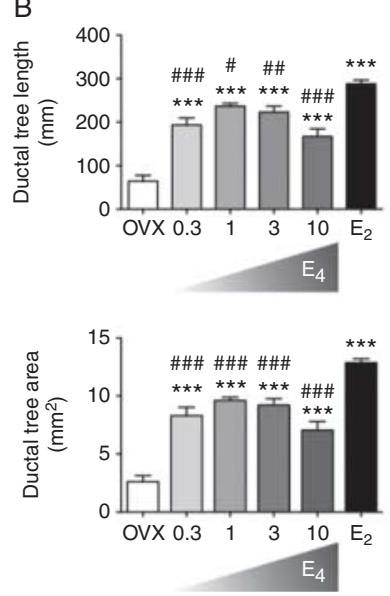

C

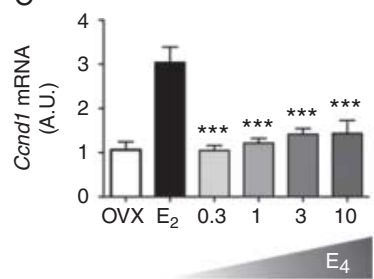

D

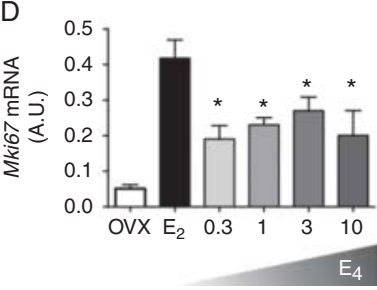

Figure 4

Comparison between the effect of $E_{4}$ and $E_{2}$ on mammary gland growth. Mice were ovariectomized and orally treated with vehicle (OVX), with $E_{2}$ $1 \mathrm{mg} / \mathrm{kg}$ per day $\left(E_{2}\right)$ or with $E_{4}$ ranging from 0.3 to $10 \mathrm{mg} / \mathrm{kg}$ per day $\left(E_{4}\right)$ for a period of 14 days. (A) Whole-mount mammary gland, scale bars $=$ $2 \mathrm{~mm}$. (B) Computer-assisted quantification of morphological parameters of whole mount mammary glands. Ductal tree length and area data are

completely absent in the vehicle-treated group (OVX), although an average of $29.4 \pm 2.2$ TEBs/gland $(n=10$ glands from five mice) was identified in the $\mathrm{E}_{4}$-treated group (Fig. 3D). After 14 days of treatment, the mean total length and the area of the epithelial network were increased by 4.9- and 3.5-fold in $\mathrm{E}_{4}$-treated mice respectively. As classically observed in this model (Sternlicht et al. 2006), the number of TEBs remained higher in the estrogen-treated mice compared with the untreated ones, but to a lower extent than after 6 days. Indeed, after 14 days of treatment, most of TEBs had regressed and became histologically simpler. The proliferative status of the $\mathrm{E}_{4}$-treated mammary glands was confirmed by Ki67 immunolabeling (Fig. 3E). In contrast to what was observed for mammary gland from OVX mice that did not express Ki67, the labeling revealed the presence of proliferating cells in TEBs and in ducts of $\mathrm{E}_{4}$-treated mice.

\section{$E_{4}$ has a weaker stimulatory effect on mammary gland than $E_{2}$}

We then compared the effect of $\mathrm{E}_{4}$ to a physiological concentration of $\mathrm{E}_{2}$. OVX mice were orally treated with $\mathrm{E}_{4}\left(0.3,1,3\right.$, or $10 \mathrm{mg} / \mathrm{kg}$ per day) or with $\mathrm{E}_{2}$ ( $1 \mathrm{mg} / \mathrm{kg}$ per day) during 14 days (Fig. 4A). The serum levels of $\mathrm{E}_{2}$ and $\mathrm{E}_{4}$ measured $3 \mathrm{~h}$ after oral administration are given in Table 1 . The concentration range used for $\mathrm{E}_{4}$ was established to start within the physiological and expressed as mean \pm S.E.M., $n=5 .{ }^{* * *} P<0.001$ vs OVX; ${ }^{\#} P<0.05$, ${ }^{\# \#} P<0.01$, ${ }^{\# \# \#} P<0.001$ vs $E_{2}$. (C) Ccnd1 (cyclin D1) mRNA and (D) Mki67 (Ki67) mRNA expression level of epithelial cells isolated from mammary gland. Results are expressed in arbitrary units (U.A.), mean \pm s.E.M., $n=5,{ }^{*} P<0.05$, $* * * P<0.001$ vs $E_{2}$. A full colour version of this figure is available via http://dx.doi.org/10.1530/JOE-14-0549.

therapeutic ranges and to exceed them (Coelingh Bennink et al. 2008a). Despite doses of $\mathrm{E}_{4}$ resulting in a plasma concentration up to 300 -fold over that of $E_{2}, E_{4}$ promoted epithelial growth only by $55-75 \%$ of the total length of the gland area achieved with $\mathrm{E}_{2}$ (Fig. 4B). The expression of cyclin D1 mRNA, which is induced by $\mathrm{E}_{2}$ and correlates with proliferation (Liu et al. 2002), was significantly lower in mammary epithelial cells of mice treated with $E_{4}$ than that with $\mathrm{E}_{2}$, and is even comparable with untreated mice (Fig. 4C). Ki67 mRNA that is overexpressed during cell proliferation was also significantly lower (Fig. 4D).

\section{$E R \alpha$ drives $E_{4}$-mediated stimulation of mammary gland growth}

While ER $\beta$ is dispensable for mammary gland elongation (Forster et al. 2002), $\mathrm{E}_{2}$ contributes to mammary epithelium proliferation and morphogenesis by paracrine

Table 1 Circulating levels of $E_{2}$ and $E_{4}$ measured $3 \mathrm{~h}$ after oral administration

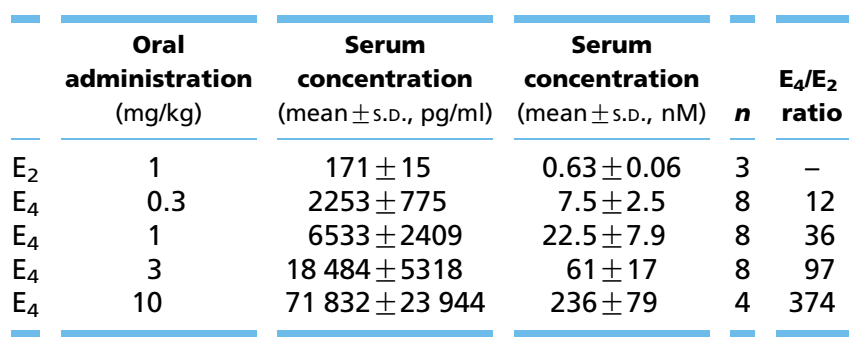

http://joe.endocrinology-journals.org DOI: 10.1530/JOE-14-0549
C) 2015 Society for Endocrinology Printed in Great Britain 
A

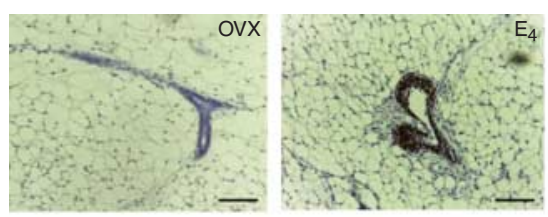

B

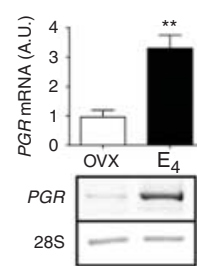

C

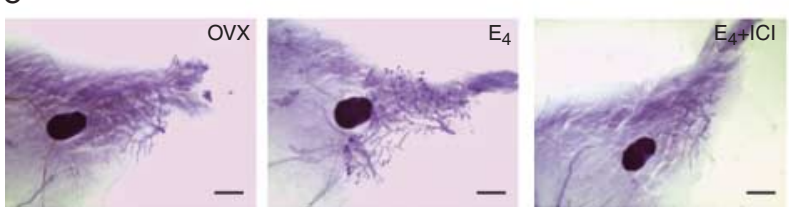

D

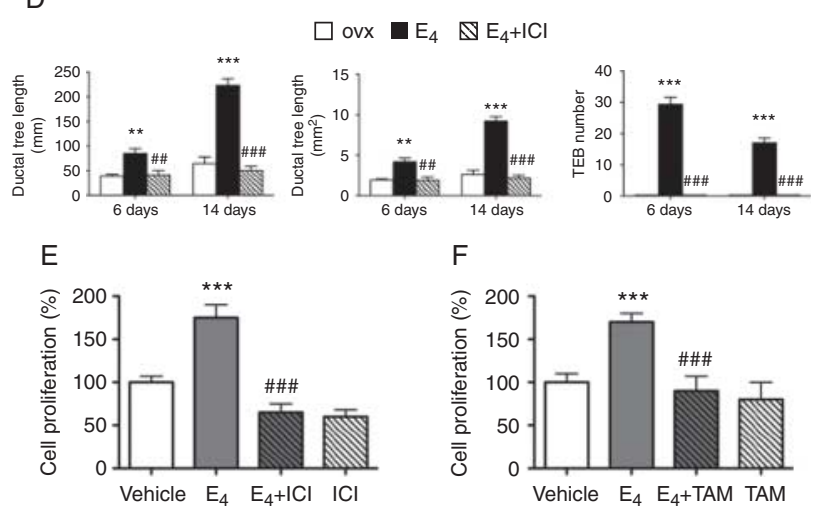

\section{Figure 5}

$E R \propto$ drives $E_{4}$ activity on mammary gland growth and $H B E$ cell proliferation. (A) Histological sections of mammary gland, stained with an anti-PGR antibody, from OVX or $E_{4}(3 \mathrm{mg} / \mathrm{kg}$ per day)-treated mice after 6 days, magnification 20X. Scale bars $=100 \mu \mathrm{m}$. (B) Pgr mRNA expression level of epithelial cells isolated from mammary gland from OVX or $E_{4}(3 \mathrm{mg} / \mathrm{kg}$ per day)-treated mice after 6 days. Data are expressed as mean \pm s.E.M., $n=5$. $* * P<0.01$ vs OVX. (C) Whole-mount mammary gland from ovariectomized mice orally treated with vehicle $(\mathrm{OVX})$ or with $\mathrm{E}_{4} 3 \mathrm{mg} / \mathrm{kg}$ per day alone $\left(\mathrm{E}_{4}\right)$ or associated with s.c. injection of ICl 182780 used at $30 \mathrm{mg} / \mathrm{kg}\left(E_{4}+\mathrm{ICI}\right)$ for a period of 6 days. Scale bars $=2 \mathrm{~mm}$. (D) Computer-assisted quantification

signaling through $\mathrm{ER} \alpha$ (Mallepell et al. 2006). When activated by $\mathrm{E}_{2}, \mathrm{ER} \alpha$ promotes the expression of PGR in the mammary epithelium (Beleut et al. 2010). In order to define whether $\mathrm{E}_{4}$ activates mammary epithelium $\mathrm{ER} \alpha$, the expression of PGR was evaluated in vivo. PGR proteins were expressed in the mammary epithelium of $\mathrm{E}_{4}$-treated mice, but not of OVX untreated mice (Fig. 5A). Pgr mRNA was overexpressed under $\mathrm{E}_{4}$ treatment (Fig. 5B). In addition, the pure ER $\alpha$ antagonist ICI 182780 completely blocked the elongation of the ductal tree induced by $\mathrm{E}_{4}$ (Fig. 5C). Quantification of total ductal tree and length and TEB number confirmed these observations (Fig. 5D). In vitro both ICI 182780 and tamoxifen (an ER $\alpha$ antagonist in the breast) also abolished the stimulating effect of $\mathrm{E}_{4}$ on $\mathrm{HBE}$ cell proliferation (Fig. 5E and F). Altogether, these in vitro and in vivo results support that $\mathrm{E}_{4}$ exerts genomic effects through $\mathrm{ER} \alpha$ and that this receptor is involved in the proliferative effect of $\mathrm{E}_{4}$ on human mammary epithelial cells and mouse mammary gland.

\section{$E_{4}$ partially antagonizes the stimulatory effect of $E_{2}$ on HBE cell proliferation and mammary gland growth}

We then evaluated the impact of a combined administration of $\mathrm{E}_{4}$ and $\mathrm{E}_{2}$ on $\mathrm{HBE}$ cell proliferation and on mammary gland growth. HBE cells were exposed of morphological parameters of whole-mount mammary glands obtained as in (C). Ductal tree length and area data and TEB number are expressed as mean \pm s.E.M., $n=5 .{ }^{* *} P<0.01, * * * P<0.001$ vs OVX; ${ }^{\# \#} P<0.01,{ }^{\# \# \#} P<0.001$ vs $E_{4}$. (E and F) Proliferation of HBE cells treated with vehicle, $E_{4}(1 \mu M)$, and/or with ICI $182780(\mathrm{ICl}, 1 \mu \mathrm{M})$ or tamoxifen (TAM, $1 \mu \mathrm{M})$ measured by $\left[{ }^{3} \mathrm{H}\right]$ thymidine incorporation. Results are expressed as $\%$ of vehicle normalized at $100 \%$, mean \pm s.E.m., $n=3 . * * * P<0.001$ vs vehicle,

$\# \# \#<0.001$ vs $E_{4}$. TEB, terminal end bud. A full colour version of this figure is available via http://dx.doi.org/10.1530/JOE-14-0549.

in vitro to a maximal stimulatory concentration of $\mathrm{E}_{2}$ $(10 \mathrm{nM})$ combined with increasing concentrations of $\mathrm{E}_{4}$ (10-1000 nM). $\mathrm{E}_{4}$ antagonized the effect of $\mathrm{E}_{2}$ in a dosedependent pattern (Fig. 6A). In vivo mice received a daily oral physiological dose of $\mathrm{E}_{2}$ ( $1 \mathrm{mg} / \mathrm{kg}$ per day) either alone or in combination with $\mathrm{E}_{4}$ at a concentration of $0.3,1,3$, or $10 \mathrm{mg} / \mathrm{kg}$ per day. After 14 days of treatment, exposure to the combination of $\mathrm{E}_{2}+\mathrm{E}_{4}$ decreased the total length and the area of the epithelial network induced by treatment with $\mathrm{E}_{2}$ alone by $17-38 \%$ (Fig. 6B). In addition, the combination of $\mathrm{E}_{2}+\mathrm{E}_{4}$ decreased cyclin D1 and Ki67 mRNA expression by 23-100\% in mammary epithelium (Fig. 6C and D) on $\mathrm{E}_{2}$ treatment. Altogether, these results support that $\mathrm{E}_{4}$ is able to partially antagonize the effect of $\mathrm{E}_{2}$ on breast epithelium proliferation in vitro and in vivo.

\section{Discussion}

Despite benefits in contraception and MHT, debates over harmful effects of estrogen have been intensified. Even if they are required for breast physiology, particularly during pregnancy in preparation for lactation, their mammary impact is usually considered to be deleterious because of their mitogenic activity. Thus, there is considerable interest in developing COC or MHT with new estrogen having minimal venous thromboembolism impact and

Published by Bioscientifica Ltd 
A

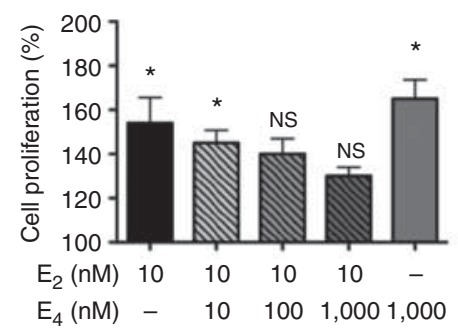

B

$\square$ OVX $\square \mathrm{E}_{2} \quad \square \mathrm{E}_{2}+\mathrm{E}_{4} 0.3$

$\square \mathrm{E}_{2}+\mathrm{E}_{4} 1 \square \mathrm{E}_{2}+\mathrm{E}_{2} 3 \square \mathrm{E}_{2}+\mathrm{E}_{4} 10$
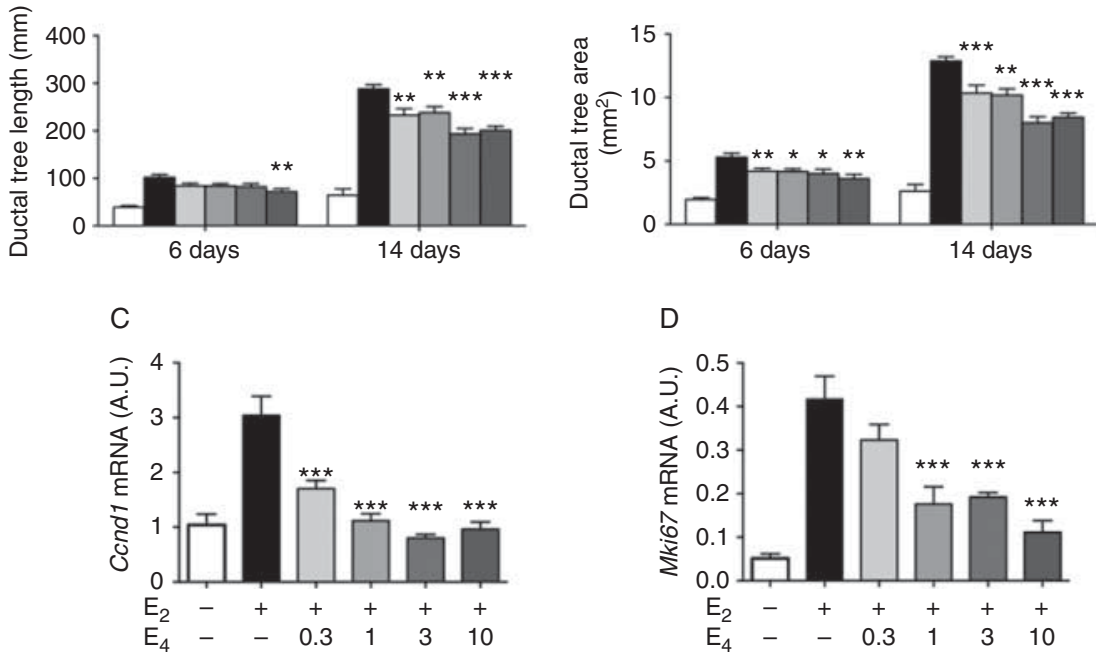

Figure 6

Effect of combination of $E_{2}$ and $E_{4}$ on $\mathrm{HBE}$ cell proliferation and mammary gland growth. (A) Effect of $E_{2}, E_{4}$, and their combination $\left(E_{2}+E_{4}\right)$ on $H B E$ cell proliferation measured by $\left[{ }^{3} \mathrm{H}\right]$ thymidine incorporation and expressed as $\%$ of vehicle normalized at $100 \%$, mean \pm S.E.M. $(n=3)$. ${ }^{*} P<0.05$, NS, not significant vs vehicle. (B) Computer-assisted quantification of morphological parameters of whole-mount mammary glands from ovariectomized mice orally treated with vehicle (OVX), $E_{2} 1 \mathrm{mg} / \mathrm{kg}$ per day alone $\left(E_{2}\right)$, or associated with $E_{4}$ used at $0.3,1,3$, or $10 \mathrm{mg} / \mathrm{kg}$ per day $\left(E_{2}+E_{4}\right)$ for a period

lower breast proliferative capacity. In this study, we report that $\mathrm{E}_{4}$ acts on breast proliferation through $\mathrm{ER} \alpha$ less efficiently than $\mathrm{E}_{2}$, in vitro and in vivo. More interestingly, when coadministered, $\mathrm{E}_{4}$ is able to partially antagonize the $\mathrm{E}_{2}$-induced proliferation of HBE cells and the mouse mammary gland growth.

Similar to $\mathrm{E}_{2}, \mathrm{E}_{4}$ stimulated the proliferation of human mammary epithelial cells in vitro and murine breast growth in vivo through $\mathrm{ER} \alpha$, because ICI 182780 and tamoxifen blocked this effect. This ER $\alpha$-dependent activation induced PGR expression, a well-described process regulated by $\mathrm{E}_{2}$ (Horwitz et al. 1978, Vienonen et al. 2002). However, $\mathrm{E}_{4}$ stimulated breast proliferation with a 100 -fold weaker efficacy than $\mathrm{E}_{2}$ in vitro as well as in vivo. of 6 or 14 days. Ductal tree length and area data are expressed as mean \pm S.E.M., $n=10$ glands from five mice. $* P<0.05, * * P<0.01, * * * P<0.001$ vs $E_{2}$ of the corresponding period of 6 or 14 days. (C) Cond 1 (cyclin D1) mRNA and (D) Mki67 (Ki67) mRNA expression level of epithelial cells isolated from mammary gland of ovariectomized mice orally treated for 14 days with vehicle or with $E_{2} 1 \mathrm{mg} / \mathrm{kg}$ per day alone or associated with $E_{4}$ doses ranging from 0.3 to $10 \mathrm{mg} / \mathrm{kg}$ per day. Data are expressed as mean \pm s.E.M., $n=5 . * * * P<0.001$ vs $E_{2}$.

This is consistent with competitive binding studies showing that $\mathrm{E}_{4}$ exhibits considerably lower affinity than $\mathrm{E}_{2}$ toward ER $\alpha$ (Martucci \& Fishman 1976, Tseng \& Gurpide 1976, 1978, Visser et al. 2008), and with the observation that $\mathrm{E}_{4}$ was less potent than $\mathrm{E}_{2}$ to increase breast cancer cell line proliferation and migration (Jozan et al. 1981, Giretti et al. 2014, Liu et al. 2014).

The dose range of $\mathrm{E}_{4}$ administered orally in this study was defined to cover and exceed the physiological levels of $\mathrm{E}_{4}$ detected in the plasma of pregnant women (3 nM), in fetal blood (45 nM) (Coelingh Bennink et al. 2008a), as well as in serum from a clinical trial where $5-20 \mathrm{mg} /$ day $\mathrm{E}_{4}$ was administered to women of reproductive age (Foidart, JM. Congress of Eur. Soc. Gynecol. 2013, personal 
communication). This range of $\mathrm{E}_{4}$ doses induced circulating levels of approximately ten- to 400-fold higher than those of $\mathrm{E}_{2}$ tested in this study. Despite these large differences, the stimulation of mammary gland growth by $\mathrm{E}_{4}$ remained at most $55 \%$ of that by $\mathrm{E}_{2}$. $\mathrm{E}_{4}$ was unable to increase cyclin D1 expression, an ER $\alpha$-inducible gene that governs $\mathrm{E}_{2}$-dependent epithelial cell growth in mammary gland (Liu et al. 2002, Casimiro et al. 2013). At these concentrations, $\mathrm{E}_{4}$ has been reported to significantly prevent osteoporosis and hot flushes in preclinical rat models (Visser \& Coelingh Bennink 2009). Altogether, these results highlight that $\mathrm{E}_{4}$ could be suitable to control reproduction, osteoporosis, and vasomotor symptoms with limited impact on breast proliferation.

The concomitant exposure to $\mathrm{E}_{2}$ and $\mathrm{E}_{4}$ in vitro and in vivo revealed that $\mathrm{E}_{4}$ partially antagonized the proliferation induced by $E_{2}$ on $\mathrm{HBE}$ cell proliferation and on mammary gland growth. This antagonistic effect was also evidenced for cyclin D1 and Ki67 mRNA expression. It was maximal in vitro and in vivo when the dose of $\mathrm{E}_{4}$ was 100 times higher than that of $\mathrm{E}_{2}$. Giretti et al. (2014) recently showed that $\mathrm{E}_{4}$ administration to malignant human breast adenocarcinoma T47-D cells weakly stimulated their cytoskeleton remodeling and migration. However, when $\mathrm{E}_{2}$ was present, $\mathrm{E}_{4}$ counteracted the stimulatory actions of $\mathrm{E}_{2}$. Estriol $\left(\mathrm{E}_{3}\right)$, another estrogen associated with pregnancy, has also been described as a weak estrogen with mixed agonist/antagonist activity (Clark \& Markaverich 1984, Melamed et al. 1997).

The precise molecular mechanism by which $\mathrm{E}_{4}$ antagonizes $E_{2}$ on epithelial breast cell proliferation has not been evaluated in this study. The molecular and kinetic basis for the mixed agonist/antagonist activity of $\mathrm{E}_{3}$ has been suggested to be the consequence of a complex equilibrium among several ER $\alpha$ species: unliganded $\mathrm{hER} \alpha$ monomers and dimers; $\mathrm{E}_{2}$-hER $\alpha$ monomers and dimers; $\mathrm{E}_{3}-\mathrm{hER} \alpha$ monomers and dimers; and $\mathrm{E}_{3}-\mathrm{E}_{2}-\mathrm{hER}$ heterodimers. It is plausible that similar plurality of $\mathrm{ER} \alpha$ complexes occurs in the presence of $\mathrm{E}_{4}+\mathrm{E}_{2}$ and causes variable interactions with estrogen-responsive elements (ERE) comparable to those described with $\mathrm{E}_{2}+\mathrm{E}_{3}$ (Melamed et al. 1997). A differential activation by $E_{2}$ and $E_{4}$ of nuclear (genomic) and extra-nuclear (nongenomic) effects of ER $\alpha$ could also be involved as reported in uterus, vasculature, and breast cancer cells in the study reported by Abot et al. (2014).

Whatever the complex mechanisms of ER $\alpha$ activation by $\mathrm{E}_{4}+\mathrm{E}_{2}$ may be, our quantitative analyses demonstrate that $\mathrm{E}_{4}$ acts on $\mathrm{ER} \alpha$ in the breast as a weak estrogen agonist and as an $\mathrm{E}_{2}$ antagonist. Our data contribute to the emerging hypothesis that $\mathrm{E}_{4}$ may be a naturally occurring ER modulator in the breast that may be considered as a potential new estrogen for clinical use with a reduced impact on breast proliferation.

\section{Declaration of interest}

J M F is Professor at the University of Liege and Scientific Consultant for Uteron Pharma. M M is Scientific Consultant for Uteron Pharma.

\section{Funding}

This work was supported by grants from the Fonds de la Recherche Scientifique - FNRS (F.R.S.-FNRS, Belgium): FRSM 3.4557.12, FRSM 3.4567.11, Télévie 7.4524.11, Télévie 7.4604.13; the Fondation contre le Cancer (foundation of public interest, Belgium), the Fonds spéciaux de la Recherche (University of Liège): FSRC-12/64, FSRC-12/92, FSRC-14/89, FSRC14/65, FSRC-14/109, FSRC-14/62; the Centre Anticancéreux près I' Université de Liège, the Fonds Léon Fredericq (University of Liège), the Direction Générale Opérationnelle de I'Economie, de I'Emploi et de la Recherche from the Service Public de Wallonie (DGO6, SPW, Belgium): P.P.P. 917008; the Interuniversity Attraction Poles Programme - Belgian Science Policy (Brussels, Belgium): IAP Phase VII - P7/03; the Plan National Cancer (Service Public Fédéral) and the Actions de Recherche Concertées (University of Liege, Belgium): A.R.C. 11/16-02.

\section{Author contribution statement}

C G designed and performed experiments, analyzed data, and prepared the figures and wrote the manuscript. S B developed and performed all computer assisted quantification analysis. L C and A C contributed to in vitro experiments. A $\mathrm{G}$ supervised in vitro experiments and reviewed the manuscript. E T, M M, C M, and A N gave scientific advices along the study. C P supervised experiment design, analyzed data, and wrote the manuscript. J M F initiated and supervised the project and critically reviewed the manuscript.

\section{Acknowledgements}

The authors thank Erika Konradowski for her excellent technical assistance. The authors also thank the animal care facility of the GIGA of the University of Liège.

\section{References}

Abot A, Fontaine C, Buscato M, Solinhac R, Flouriot G, Fabre A, Drougard A, Rajan S, Laine M, Milon A et al. 2014 The uterine and vascular actions of estetrol delineate a distinctive profile of estrogen receptor $\alpha$ modulation, uncoupling nuclear and membrane activation. EMBO Molecular Medicine 10 1328-1346. (doi:10.15252/emmm.201404112)

Anderson E, Clarke RB \& Howell A 1998 Estrogen responsiveness and control of normal human breast proliferation. Journal of Mammary Gland Biology and Neoplasia 3 23-35. (doi:10.1023/A:1018718117113) Anderson GL, Chlebowski RT, Rossouw JE, Rodabough RJ, McTiernan A, Margolis KL, Aggerwal A, David Curb J, Hendrix SL, Allan Hubbell F et al. 2006 Prior hormone therapy and breast cancer risk in the Women's Health Initiative randomized trial of estrogen plus progestin. Maturitas 55 103-115. (doi:10.1016/j.maturitas.2006.05.004)

Ayyanan A, Laribi O, Schuepbach-Mallepell S, Schrick C, Gutierrez M, Tanos T, Lefebvre G, Rougemont J, Yalcin-Ozuysal O \& Brisken C 2011

Published by Bioscientifica Ltd. 
Perinatal exposure to bisphenol a increases adult mammary gland progesterone response and cell number. Molecular Endocrinology 25 1915-1923. (doi:10.1210/me.2011-1129)

Beleut M, Rajaram RD, Caikovski M, Ayyanan A, Germano D, Choi Y, Schneider P \& Brisken C 2010 Two distinct mechanisms underlie progesterone-induced proliferation in the mammary gland. PNAS $\mathbf{1 0 7}$ 2989-2994. (doi:10.1073/pnas.0915148107)

Brisken C \& O'Malley B 2010 Hormone action in the mammary gland. Cold Spring Harbor Perspectives in Biology 2 a003178. (doi:10.1101/ cshperspect.a003178)

Canonico M 2014 Hormone therapy and hemostasis among postmenopausal women: a review. Menopause 21 753-762. (doi:10.1097/GME. 0000000000000296)

Casimiro MC, Wang C, Li Z, Di Sante G, Willmart NE, Addya S, Chen L, Liu Y, Lisanti MP \& Pestell RG 2013 Cyclin D1 determines estrogen signaling in the mammary gland in vivo. Molecular Endocrinology 27 1415-1428. (doi:10.1210/me.2013-1065)

Clark JH \& Markaverich BM 1984 The agonistic and antagonistic actions of estriol. Journal of Steroid Biochemistry 20 1005-1013. (doi:10.1016/ 0022-4731(84)90011-6)

Coelingh Bennink F, Holinka CF, Visser M \& Coelingh Bennink HJ $2008 a$ Maternal and fetal estetrol levels during pregnancy. Climacteric 11(Suppl 1) 69-72. (doi:10.1080/13697130802056321)

Coelingh Bennink HJ, Heegaard AM, Visser M, Holinka CF \& Christiansen C 2008b Oral bioavailability and bone-sparing effects of estetrol in an osteoporosis model. Climacteric 11(Suppl 1) 2-14. (doi:10.1080/13697130701798692)

Fenton SE 2006 Endocrine-disrupting compounds and mammary gland development: early exposure and later life consequences. Endocrinology 147 S18-S24. (doi:10.1210/en.2005-1131)

Foidart JM, Desreux J, Pintiaux A \& Gompel A 2007 Hormone therapy and breast cancer risk. Climacteric 10(Suppl 2) 54-61. (doi:10.1080/ 13697130701598324)

Forster C, Makela S, Warri A, Kietz S, Becker D, Hultenby K, Warner M \& Gustafsson JA 2002 Involvement of estrogen receptor $\beta$ in terminal differentiation of mammary gland epithelium. PNAS 99 15578-15583. (doi:10.1073/pnas.192561299)

Frangi I, Keppenne V, Coppens L, Bonnet P, Andrianne R \& de Leval J 1998 Antegrade scrotal embolization of varicocele: results. Acta Urologica Belgica 66 5-8.

Giretti MS, Montt Guevara MM, Cecchi E, Mannella P, Palla G, Spina S, Bernacchi G, Di Bello S, Genazzani AR, Genazzani AD et al. 2014 Effects of estetrol on migration and invasion in T47-D breast cancer cells through the actin cytoskeleton. Frontiers in Endocrinology 580. (doi:10.3389/fendo.2014.00080)

Hagen AA, Barr M \& Diczfalusy E 1965 Metabolism of 17- $\beta$-oestradiol4-14-C in early infancy. Acta Endocrinologica 49 207-220.

Hammond GL, Hogeveen KN, Visser M \& Coelingh Bennink HJ 2008 Estetrol does not bind sex hormone binding globulin or increase its production by human HepG2 cells. Climacteric 11(Suppl 1) 41-46. (doi:10.1080/13697130701851814)

Holinka CF, Diczfalusy E \& Coelingh Bennink HJ $2008 a$ Estetrol: a unique steroid in human pregnancy. Climacteric 11(Suppl 1) 1. (doi:10.1080/ 13697130802040077)

Holinka CF, Brincat M \& Coelingh Bennink HJ $2008 b$ Preventive effect of oral estetrol in a menopausal hot flush model. Climacteric 11(Suppl 1) 15-21. (doi:10.1080/13697130701822807)

Horwitz KB, Koseki Y \& McGuire WL 1978 Estrogen control of progesterone receptor in human breast cancer: role of estradiol and antiestrogen. Endocrinology 103 1742-1751. (doi:10.1210/endo-103-5-1742)

Jozan S, Kreitmann B \& Bayard F 1981 Different effects of oestradiol, oestriol, oestetrol and of oestrone on human breast cancer cells (MCF-7) in long term tissue culture. Acta Endocrinologica 98 73-80.

Lai JN, Wu CT, Chen PC, Huang CS, Chow SN \& Wang JD 2011 Increased risk for invasive breast cancer associated with hormonal therapy: a nation-wide random sample of 65,723 women followed from 1997 to 2008. PLOS ONE 6 e25183. (doi:10.1371/journal.pone. 0025183)

Lambe M, Hsieh C, Trichopoulos D, Ekbom A, Pavia M \& Adami HO 1994 Transient increase in the risk of breast cancer after giving birth. New England Journal of Medicine 331 5-9. (doi:10.1056/ NEJM199407073310102)

LaRocca J, Pietruska J \& Hixon M 2011 Akt1 is essential for postnatal mammary gland development, function, and the expression of Btn1a1. PLoS ONE 6 e24432. (doi:10.1371/journal.pone.0024432)

Liu MM, Albanese C, Anderson CM, Hilty K, Webb P, Uht RM, Price RH Jr, Pestell RG \& Kushner PJ 2002 Opposing action of estrogen receptors $\alpha$ and $\beta$ on cyclin D1 gene expression. Journal of Biological Chemistry $\mathbf{2 7 7}$ 24353-24360. (doi:10.1074/jbc.M201829200)

Liu S, Ruan X, Schultz S, Neubauer H, Fehm T, Seeger H \& Mueck AO 2014 Oestetrol stimulates proliferation and oestrogen receptor expression in breast cancer cell lines: comparison of four oestrogens. European Journal of Contraception \& Reproductive Health Care 12 1-7. (doi:10.3109/ 13625187.2014.951997)

Mallepell S, Krust A, Chambon P \& Brisken C 2006 Paracrine signaling through the epithelial estrogen receptor $\alpha$ is required for proliferation and morphogenesis in the mammary gland. PNAS 103 2196-2201. (doi:10.1073/pnas.0510974103)

Martucci C \& Fishman J 1976 Uterine estrogen receptor binding of catecholestrogens and of estetrol (1,3,5(10)-estratriene-3,15 $\alpha, 16 \alpha$, 17ß-tetrol). Steroids 27 325-333. (doi:10.1016/0039-128X(76)90054-4)

Melamed M, Castano E, Notides AC \& Sasson S 1997 Molecular and kinetic basis for the mixed agonist/antagonist activity of estriol. Molecular Endocrinology 11 1868-1878. (doi:10.1210/mend.11.12.0025)

O'Brien SH 2014 Contraception-related venous thromboembolism in adolescents. Seminars in Thrombosis and Hemostasis 40 66-71. (doi:10.1055/s-0033-1363469)

Rossouw JE, Anderson GL, Prentice RL, LaCroix AZ, Kooperberg C, Stefanick ML, Jackson RD, Beresford SA, Howard BV, Johnson KC et al. 2002 Risks and benefits of estrogen plus progestin in healthy postmenopausal women: principal results From the Women's Health Initiative randomized controlled trial. Journal of the American Medical Association 288 321-333. (doi:10.1001/jama.288.3.321)

Rudel RA, Fenton SE, Ackerman JM, Euling SY \& Makris SL 2011 Environmental exposures and mammary gland development: state of the science, public health implications, and research recommendations. Environmental Health Perspectives 119 1053-1061. (doi:10.1289/ehp.1002864)

Russo IH \& Russo J 1998 Role of hormones in mammary cancer initiation and progression. Journal of Mammary Gland Biology and Neoplasia 3 49-61. (doi:10.1023/A:1018770218022)

Scarabin PY 2014 Hormone therapy and venous thromboembolism among postmenopausal women. Frontiers in Hormone Research 43 21-32.

Soille P 1999 Morphological Image Analysis: Principles and Applications. Berlin Heidelberg: Springer-Verlag.

Stahlberg C, Pedersen AT, Lynge E, Andersen ZJ, Keiding N, Hundrup YA, Obel EB \& Ottesen B 2004 Increased risk of breast cancer following different regimens of hormone replacement therapy frequently used in Europe. International Journal of Cancer 109 721-727. (doi:10.1002/ ijc.20016)

Sternlicht MD, Kouros-Mehr H, Lu P \& Werb Z 2006 Hormonal and local control of mammary branching morphogenesis. Differentiation $\mathbf{7 4}$ 365-381. (doi:10.1111/j.1432-0436.2006.00105.x)

Sturdee DW, Pines A, International Menopause Society Writing Group, Archer DF, Baber RJ, Barlow D, Birkhauser MH, Brincat M, Cardozo L, de Villiers TJ et al. 2011 Updated IMS recommendations on postmenopausal hormone therapy and preventive strategies for midlife health. Climacteric 14 302-320. (doi:10.3109/13697137.2011.570590)

Tseng L \& Gurpide E 1976 Competition of estetrol and ethynylestradiol with estradiol for nuclear binding in human endometrium. Journal of Steroid Biochemistry 7 817-822. (doi:10.1016/0022-4731(76)90184-9) 
Tseng L \& Gurpide E 1978 Heterogeneity of saturable estradiol binding sites in nuclei of human endometrium. Estetrol studies. Journal of Steroid Biochemistry 9 1145-1148. (doi:10.1016/0022-4731 (78)90003-1)

Turkoz FP, Solak M, Petekkaya I, Keskin O, Kertmen N, Sarici F, Arik Z, Babacan T, Ozisik Y \& Altundag K 2013 Association between common risk factors and molecular subtypes in breast cancer patients. Breast 22 344-350. (doi:10.1016/j.breast.2012.08.005)

Vienonen A, Syvala H, Miettinen S, Tuohimaa P \& Ylikomi T 2002 Expression of progesterone receptor isoforms A and B is differentially regulated by estrogen in different breast cancer cell lines. Journal of Steroid Biochemistry and Molecular Biology 80 307-313. (doi:10.1016/ S0960-0760(02)00027-4)

Visser M \& Coelingh Bennink HJ 2009 Clinical applications for estetrol. Journal of Steroid Biochemistry and Molecular Biology 114 85-89. (doi:10.1016/j.jsbmb.2008.12.013)

Visser M, Foidart JM \& Coelingh Bennink HJ 2008 In vitro effects of estetrol on receptor binding, drug targets and human liver cell metabolism. Climacteric 11(Suppl 1) 64-68. (doi:10.1080/ 13697130802050340)

Received in final form 21 October 2014

Accepted 29 October 2014

Accepted Preprint published online 30 October 2014
Published by Bioscientifica Ltd. 